\title{
Characterization of Extracellular Chitinase from Bacterial Isolate 99 and Enterobacter sp. G-1 from Matsue City, Japan
}

\author{
MARIA ENDO MAHATA ${ }^{1 *}$, ABDI DHARMA ${ }^{2}$, IRSAN RYANTO ${ }^{1}$, AND YOSE RIZAL ${ }^{1}$ \\ ${ }^{1}$ Department of Animal Nutrition and Feed Science, Faculty of Animal Science, \\ ${ }^{2}$ Department of Chemistry, Faculty of Mathematics and Natural Science, \\ Universitas Andalas, Kampus Limau Manis, Padang 25163, Indonesia
}

\begin{abstract}
One hundred and twenty isolates of chitosanase producing bacteria were screened from water and soil from localies around Matsue city, Japan. In previous experiments, four isolates (isolates 96, 97, 99, and 100 strain ) were analyzed for their chitosanase characteristics, and one of the isolates (99) was detected as being both a chitosanase and a chitinase producer. Characteristics of the chitinase enzyme were analyzed in this study. Chitinase from bacterial isolate 99 showed higher activities compared to that Enterobacter sp. G-1 (isolated from water in Matsue city, Japan), the activity was $0.039 \mathrm{U} / \mathrm{ml}$ and the specific activity was $0.56 \mathrm{U} / \mathrm{mg}$ protein, while those from Enterobacter sp. G-1 were $0.029 \mathrm{U} / \mathrm{ml}$ and $0.48 \mathrm{U} / \mathrm{mg}$ protein respectively. Chitinase from isolate 99 was stable in a pH range between 4-7, while that from Enterobacter sp. G-1 was stable in pH range 3-7. Optimum pH of the chitinase produced by isolate 99 was 5 whereas the chitinase from Enterobacter sp. G-1 it was pH 7. Chitinase from isolate 99 was stable at temperature $20-60^{\circ} \mathrm{C}$, while that from Enterobacter sp. G-1 at $20-50^{\circ} \mathrm{C}$. Chitinase secreted by isolate 99 showed optimum temperature of $50^{\circ} \mathrm{C}$ while chitinase from Enterobacter sp. G-1 was optimal at $40^{\circ} \mathrm{C}$. Several ions $\left(\mathrm{Fe}^{2+}, \mathrm{Ba}^{2+}, \mathrm{Co}^{2+}\right)$ increased the activity of the enzyme from isolate 99 whereas $\mathrm{Ca}^{2+}$ and $\mathrm{Co}^{2+}$ increased activity of the Enterobacter sp. G-1 chitinase.
\end{abstract}

Key words: chitinase activity, $\mathrm{pH}$, temperature, metal ion

Chitinases (EC 3.2.1.14) are enzyme that catalyze the degradation of chitin into the monomer $N$-acetyl-Dglucosamine (Park et al. 1997; Yi-Wang et al. 2001). While chitosanases (EC 3.2.1.132) are glycosyl hydrolase that catalyze the degradation of chitosan into $\alpha$-D-glucosamine monomers. Chitin is a linear polymer of $N$-acetyl-Dglucosamine units linked through $\alpha$ (1-4) glycosidic bonds and distributed widely in nature as the skeletal materials of crustaceans and insects (Minoru et al. 2002), and also as a cell wall component of bacteria and fungi. Chitosan is a partially or fully deacetylated chitin. The $\alpha 1.4$ glycosidic bond at linear polymer of $N$-acetyl-D-glucosamine of chitin is very strong and the chitinase or a specific chitosanase can catalyze degradation of the bond into a simple monomer. Chitin combined with protein and (organic salt) $\mathrm{CaCO}_{3}$ form the skeletal material of crustacean and insects and this structure is involved in self defence mechanism against pathogenic bacteria and evaporation (Yamasaki 1993).

The use of protein of skeletal crustacean as a protein source in poultry feed is inhibited by chitin compounds, because the poultry's digestive tract does not produce chitinase to hydrolyze chitin. Therefore, before adding to poultry feed, the crustacean skeleton should be hydrolyzed by chitinase into simple monomers, so that poultry can then digest.

Generally, bacteria use their chitinase for degrading chitin as their carbon source, but some of them use chitinases for their self defence mechanism against pathogenic microorganisms. The characterization of chitinase from some bacteria has been undertaken, for example from Bacillus circulance WL-12, Enterobacter sp. G1, Stenotrophomonas maltophilia C3, Bacillus sp. NCTU2, Aeromonas sp. 10 S-24, Enterobacter sp. NRG4, (Park et al. 1997; Watanabe

\footnotetext{
*Corresponding author, Phone/Fax: +62-751-71464, E-mail: mariamahata2002@yahoo.com
}

et al. 1999; Zhang et al. 2001; Min-Wen et al. 2002; Ueda et al. 2003; Dahiya et al. 2005). In nature, some bacterial species can produce chitosanases which hydrolyze chitin (Shimosaka et al. 1995) and cellululose (Reyes and Corona 1997) as their substrates. Mahata et al. (2005) reported that isolate 99 could produced both chitosanase and chitinase (at first, it was found that this bacterium could only produced chitosanase, whose activity was lower than that of isolate 97). Both chitosanase activities from isolate 99 and 97 were higher than the activity of Matsuebacter chitosanotabidus 3001 (a novel chitosanase bacterium isolated from water from Matsue city, Japan) used as control bacterium. The growth rates of isolate 99 in colloidal chitin solution and solid colloidal-chitin-agar medium were higher than that of other chitinase producing bacteria $(119,130,136$, and Enterobacter sp. G-1) in the same medium. Wide clear zones were produced by isolate 99 in solid colloidal chitin agar media. So far, we do not known how many types of chitinases and chitosanases are present in nature. The aims of this research was to characterize the chitinase from isolate 99 compared with the characteristics of chitinase from chitinolytic bacterium Enterobacter sp. G-1 as a control bacterium since it produces both chitinase and chitosanase.

\section{MATERIALS AND METHODS}

Materials. The bacteria used in this experiment were isolate 99 and Enterobacter sp. G-1 from the laboratory collection of the Department of Biochemistry and Biotechnology, Faculty of Life and Environtmental Science, Shimane University, Japan.

Bacteria Culture and Chitinase Production. Single colonies of isolate 99 and Enterobacter sp. G-1 were cultured in $2 \mathrm{ml}$ of Luria Bertani medium (1\% polypepton, 0.5\% yeast extract, and $1 \% \mathrm{NaCl}$ ) at $\mathrm{pH} 7.2$ and $30^{\circ} \mathrm{C}$ for $24 \mathrm{~h}$. One $\mathrm{ml}$ of each bacteria culture (isolate 99 and Enterobacter sp. G-1) were 
taken from Luria Bertani medium and cultured in $200 \mathrm{ml}$ colloidal chitin solution. Every day, $2 \mathrm{ml}$ of each bacteria culture were taken and centrifuged at $3500 \mathrm{rpm}$ for $5 \mathrm{~min}$. After centrifugation, the supernatant was separated from the pellet (bacteria) and kept at $4^{\circ} \mathrm{C}$ for the analysis of enzyme activity, specific activity, optimum temperature, and stability, optimum $\mathrm{pH}$ and stability and also to analyze the effect of some metal ions on chitinase activity.

Chitinase Activity and Specific Activity. Chitinase activity was determinated employing modified Schales method with colloidal chitin as substrate (Imoto and Yagashita 1971). A mixture of $0.5 \mathrm{ml}$ colloidal chitin solution (pH 5.2), 1.48 ml McIlvaine buffer pH 7.0 and $20 \mu$ l chitinase sample from isolate 99 and Enterobacter sp. G-1 were incubated at $30^{\circ} \mathrm{C}$ for $30 \mathrm{~min}$ in shaking incubator. The reaction was stopped by boiling the mixture $\left(100^{\circ} \mathrm{C}\right)$ for $15 \mathrm{~min}$, and then centrifuged at $3500 \mathrm{rpm}$ for $5 \mathrm{~min}$. As much as $1.5 \mathrm{ml}$ of the supernatant was placed in a testube into which $2 \mathrm{ml}$ Schales reagent was added. The reducing sugar (product of the reaction) in the supernatant was detected spectrophotometrically (spectronic 21) at A $420 \mathrm{~nm}$. One Unit of chitinase activity equals the amount of chitinase needed to produce $1 \mu$ mol reducing sugar which was equivalent to $\mathrm{N}-\mathrm{D}$, Acetyl glucosamine per min. Specific activity is measured by comparing chitinase activity (U) with protein content of the enzyme ( $\mu$ g protein), the protein content is measured by Lowry et al. (1951) method.

Optimum Temperature and Stability. Optimum temperature for chitinase activity from isolate 99 and Enterobacter sp. G-1 were determinated at 20, 30, 40, 50, 60 , and $70^{\circ} \mathrm{C}$, and enzyme stability was determined at 20 , $30,40,50,60,70^{\circ} \mathrm{C}$ for $60 \mathrm{~min}$.

Optimum pH and Stability. Optimum pH of chitinase from isolate 99 strain and Enterobacter sp. G-1 were measured at $\mathrm{pH} 2$ to 8 by using McIlvaine buffer. The chitinases sample from both bacteria were added to colloidal chitin substrate and incubated at $30^{\circ} \mathrm{C}$ for $30 \mathrm{~min}$ after which chitinase activity was analyzed. The $\mathrm{pH}$ of chitinase stability was measured at $\mathrm{pH} 2-8$ and $30^{\circ} \mathrm{C}$ for $60 \mathrm{~min}$ and the colloidal chitin substrate was added before measuring chitinase activity.

The Effect of Metal Ions on Chitinase Activity. The effect of metal ions on chitinase activity produced by isolate 99 and Enterobacter sp. G-1 were determined employing Schales method (Imoto andYagashita 1971). The chitinase sample from both bacteria were preincubated with certain ions $\left(\mathrm{Mg}^{2+}, \mathrm{Na}^{2+}, \mathrm{Zn}^{2+}, \mathrm{Cu}^{2+}\right.$, and $\left.\mathrm{Fe}^{2+}\right)$ in Mcllvaine buffer $\mathrm{pH} 7.0$ at $30^{\circ} \mathrm{C}$ for $30 \mathrm{~min}$. The final concentration of metal ion in mixed solution was $1 \mathrm{mM}$. All ions were as chloride with the exception for $\mathrm{Cu}^{2+}$ which was a sulphate.

\section{RESULTS}

Chitinase Activity and Specific Activity. The highest chitinase activity from isolate 99 was found on fourth day incubation while that from Enterobacter sp. G-1 on the third day (Fig 1). Chitinase activity from isolate 99 was $0.039 \mathrm{U} / \mathrm{ml}$ and its specific activity was $0.56 \mathrm{U} / \mathrm{mg}$ protein. Chitinase activity from isolate 99 and its specific activity were higher than those of Enterobacter sp. G-1 which were $0.029 \mathrm{U} / \mathrm{ml}$ (Fig 2) and $0.48 \mathrm{U} / \mathrm{mg}$ protein (Fig 3).

Optimum Temperature and Stability. The optimum temperature of chitinase from isolate 99 was $50^{\circ} \mathrm{C}$, and the temperature stability range was $20-60^{\circ} \mathrm{C}$. The optimum temperature of chitinase from Enterobacter sp. G-1 was detected at $40^{\circ} \mathrm{C}$ and its temperature stability was at $20-50^{\circ} \mathrm{C}$ after 60 min incubation (Fig 4 and 5).

Optimum pH and Stability. The optimum pH of chitinase from isolate 99 was 5 and its $\mathrm{pH}$ stability range was 4 to 7 , while the optimum $\mathrm{pH}$ of chitinase from Enterobacter sp. G-1 was 7 and its $\mathrm{pH}$ stability was 3 to 7 after 60 min incubation (Fig 6 and 7).

The Effect of Metal Ions on Chitinase Activity. Several ions $\left(\mathrm{Fe}^{2+}, \mathrm{Ba}^{2+}, \mathrm{Co}^{2+}\right)$ increased the activity of enzyme from

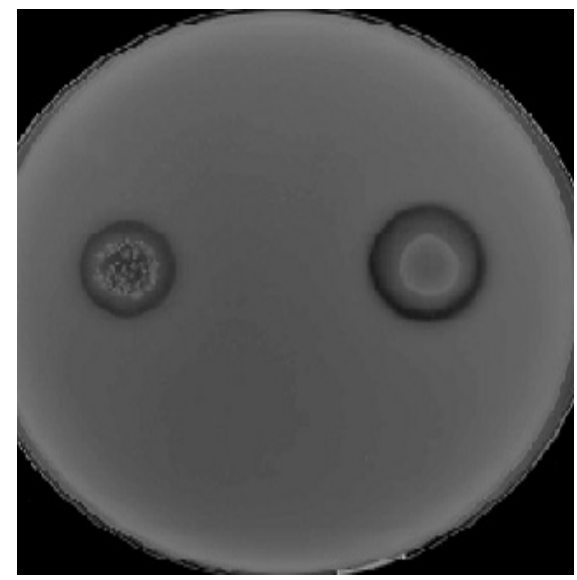

Fig 1 The clear zone of chitinase activity from isolate 99 on a solid chitin colloidal media on day 3 incubation. Right the clear zone of $10 u$ l of isolate 99 culture with diameter $1.10 \mathrm{~cm}$. Left the clear zone of $10 u$ l chitinase from isolate 99 with diameter $0.90 \mathrm{~cm}$.

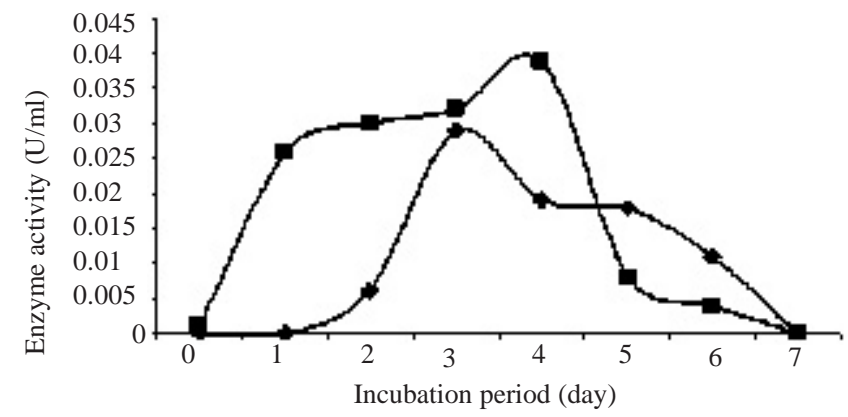

Fig 2 Chitinase activity from isolate 99 and Enterobacter sp. G-1: - - chitinase 99, ——— chitinase Enterobacter sp. G-1.

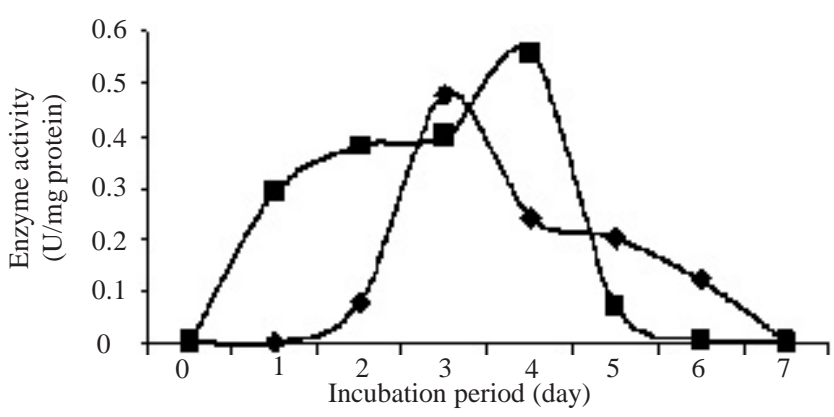

Fig 3 Chitinase specific activity from isolate 99 and Enterobacter sp. G-1: - - chitinase 99, - - - chitinase Enterobacter sp. G-1. 
isolate 99 while $\mathrm{Ca}^{2+}$ and $\mathrm{Co}^{2+}$ increased activity of the Enterobacter sp. G-1 chitinase (Table 1).

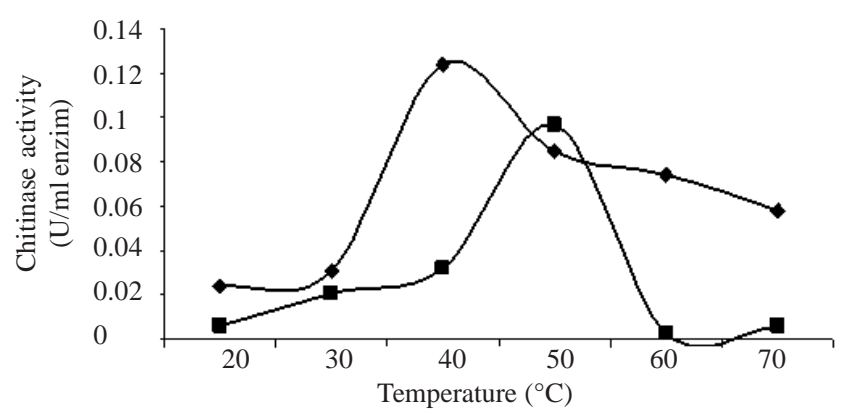

Fig 4 The effect of temperature on chitinase activity from isolate 99 and and Enterobacter sp. G-1: - — chitinase 99, —— chitinase Enterobacter sp. G-1.

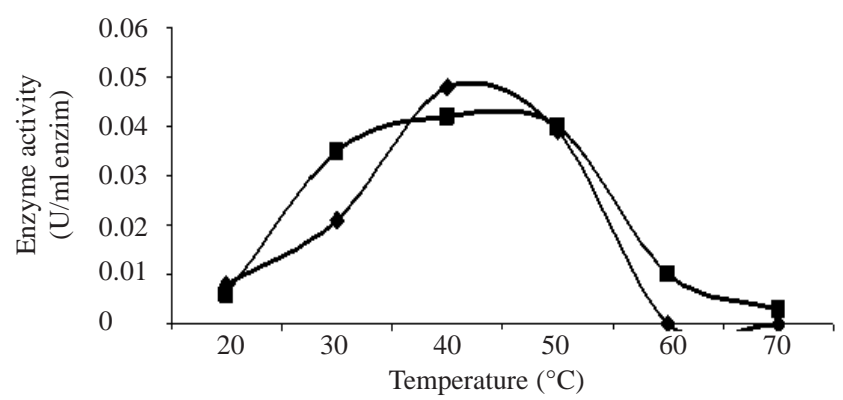

Fig 5 Chitinase temperature stability $\left({ }^{\circ} \mathrm{C}\right)$ curve from isolate 99 and Enterobacter sp. G-1: $-\downarrow$ - chitinase 99, — — chitinase Enterobacter sp. G-1.

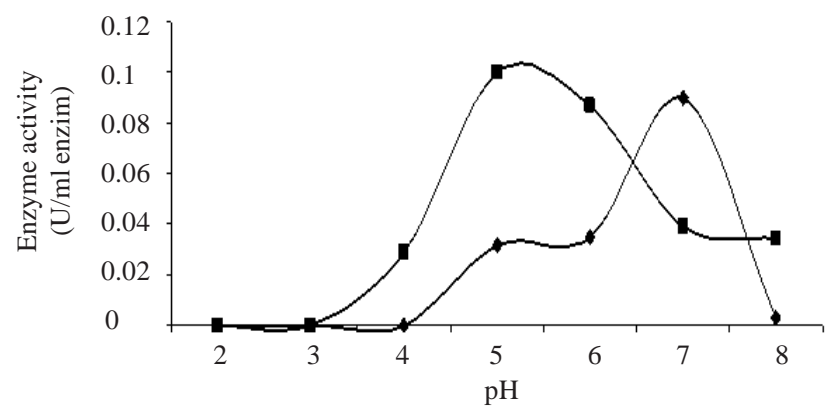

Fig 6 The effect of pH upon chitinase activity from isolate 99 and Enterobacter sp. G-1: - - chitinase 99, - - c chitinase Enterobacter sp. G-1.

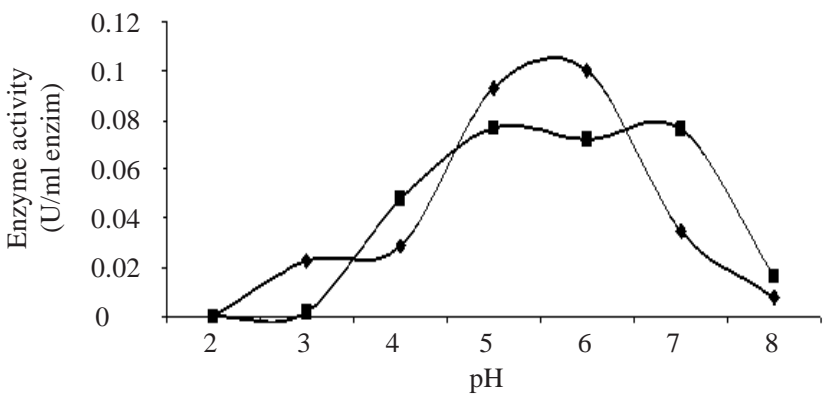

Fig 7 Chitinase $\mathrm{pH}$ stability from isolate 99 and Enterobacter sp. G-1: - — chitinase 99, ——— chitinase Enterobacter sp. G-1.

\section{DISCUSSION}

This study revealed that the activity of chitinase from isolate $99(0.039 \mathrm{U} / \mathrm{ml})$ was higher than that of Enterobacter sp. G-1 $(0.029 \mathrm{U} / \mathrm{ml})$, but its activity was lower than chitinase activity from Paneibacillus illinoisensis (3.4 U/mg) which was isolated from a garden soil containing crab shell on the west coast of Korea (Hwan et al. 2006). The chitinase from isolate 99 later will be used for hydrolyzing chitin in shrimp waste, and then the shrimp waste is used for poultry feed. Yamasaki et al. (1993) reported that Enterobacter sp. G-1 was both a chitosanase and a chitinase producing bacterium, but its chitinase activity was lower than its chitosanase activity. The highest chitinase specific activity from isolate 99 was $0.56 \mathrm{U} / \mathrm{mg}$ protein which was higher than the highest chitinase activity from Enterobacter sp. G-1 (0.48 U/mg protein). This fact indicated that chitinase protein content from both bacteria was equivalent with its activity. Compared with other bacteria, chitinase specific activity from isolate 99 in this experiment was higher than that of Stenotrophomonas maltophilia C3 (0.14 U/mg protein), but lower than purified chitinase from Pseudomonas aeruginosa Strain 385 (1.12 U/mg protein) (Thompson et al. 2001),

Table 2 Substrate specificity of chitosanase from isolate 97, 99, and Matsuebacter chitosanotabidus 3001

\begin{tabular}{cccr}
\hline \multirow{2}{*}{ Substrate } & \multicolumn{3}{c}{ Relative activity (\%) } \\
\cline { 2 - 4 } & M. Chitosanotabidus & 99 & 97 \\
\hline 80\% deacetylated chitosan & 3001 & 100 & 100 \\
$70 \%$ deacetylated chitosan & 50 & 118 & 0 \\
$90 \%$ deacetylated chitosan & 31 & 30 & 1 \\
$100 \%$ deacetylated chitosan & 8 & 13 & 20 \\
$0.5 \%$ Colloidal chitin & 0 & 21 & 0 \\
\hline
\end{tabular}

Table 1 The effect of metal ions on chitinase activity from isolate 99 and Enterobacter sp. G-1

\begin{tabular}{|c|c|c|c|c|}
\hline Ion & Bacteria & $\begin{array}{c}\text { Chitinase activity } \\
\qquad(\mathrm{U} / \mathrm{ml}) \\
\text { before incubation with ion }\end{array}$ & $\begin{array}{l}\text { Chitinase activity } \\
\qquad(\mathrm{U} / \mathrm{ml}) \\
\text { after incubation with ion }\end{array}$ & $\begin{array}{l}\text { Percentage increase or decrease* } \\
\text { after incubation with ion }\end{array}$ \\
\hline \multirow[t]{2}{*}{$\mathrm{Fe}^{2+}$} & Isolate 99 & 0.039 & 0.055 & 41.03 \\
\hline & Enterobacter sp3 G-1 & 0.029 & 0.040 & 37.93 \\
\hline \multirow[t]{2}{*}{$\mathrm{Ba}^{2+}$} & Isolate 99 & 0.039 & 0.089 & 128.21 \\
\hline & Enterobacter sp3 G-1 & 0.029 & 0.023 & $20.69 *$ \\
\hline \multirow[t]{2}{*}{$\mathrm{Ca}^{2+}$} & Isolate 99 & 0.039 & 0.040 & 2.561 \\
\hline & Enterobacter sp3 G-1 & 0.029 & 0.064 & 20.69 \\
\hline \multirow[t]{2}{*}{$\mathrm{Cu}^{2+}$} & Isolate 99 & 0.039 & 0.040 & 2.56 \\
\hline & Enterobacter sp3 G-1 & 0.029 & 0.049 & 68.97 \\
\hline \multirow[t]{2}{*}{$\mathrm{Co}^{2+}$} & Isolate 99 & 0.039 & 0.221 & 466.67 \\
\hline & Enterobacter s3p G-1 & 0.029 & 0.246 & 748.28 \\
\hline
\end{tabular}


and purified chitinase from Aspergillus fumigatus Y J- 407 (3.36 U/mg protein) (Xia et al. 2001). This experiment showed that isolate 99 was a potential chitinase producing bacterium. Its ability to produce chitinase was better than that Enterobacter sp. G-1, and it was also a potential chitosanase producing bacterium because its chitosanase activity was higher than that of Matsuebacter chitosanotabidus 3001 in previous experiments (Table 2) (Mahata et al. 2005). This experiment found that the isolate 99 is a bacterium that can produce both chitinase and chitosanase.

The optimum temperature of chitinase from isolate 99 was $50^{\circ} \mathrm{C}$ which was higher than the optimum temperature of chitinase from Enterobacter sp. G-1 $\left(40^{\circ} \mathrm{C}\right)$. This data shows that chitinase from isolate 99 was more tolerant to high temperature than chitinase from Enterobacter sp. G-1, but that its activity in optimum temperature was lower than that of Enterobacter sp. G-1. Yi -Wang et al. (2001) stated that the optimum temperature of exochitinase from Bacillus cereus was $35^{\circ} \mathrm{C}$ who it was lower than chitinase from isolate 99, but relatively similar to chitinase from Enterobacter sp. G-1. Min-Wen et al. (2002) also found that the optimum temperature range of chitinase from Bacillus sp. NCTU2 was 50 to $60^{\circ} \mathrm{C}$, and that the chitinase optimum temperature from isolate 99 was within in this range. This experiment also found that the temperature stability (incubated at $60 \mathrm{~min}$ ) of chitinase from isolate 99 was 20 to $60^{\circ} \mathrm{C}$, and for Enterobacter sp. G-1 it was between 20 to $50^{\circ} \mathrm{C}$. This data showed that chitinase from isolate 99 was more tolerant and stable at high temperature compared with chitinase fom Enterobacter sp. G-1, but that its activity was not as high as chitinase activity from Enterobacter sp. G-1. Yi-Wang et al. (2001) reported Bacillus cereus had a wide range of temperature stability, the range was from 4 to $70^{\circ} \mathrm{C}$. The temperature stability of chitinase from isolate 99 and Enterobacter sp. G-1 in these studies were within this range. Apparently, the chitinase from isolate 99 can be characterized as a thermotolerant enzyme and its stability is adequate for industrial application.

In acid conditions, chitinase from isolate 99 degraded chitin more actively than chitinase from Enterobacter sp. $\mathrm{G}-1$. In general, the optimum $\mathrm{pH}$ of chitinase from microorganisms (bacteria, yeast, fungi) is 3.5 to 8 (Koga et al. 1999), and the optimum pH of chitinase from isolate 99 and Enterobacter sp. G-1 in these experiments were within the range reported. Chitinase activity from isolate 99 was stable at pH 4 to7, while Enterobacter sp. G-1 was stable at $\mathrm{pH} 3$ to 7. Chitinase from both bacteria were stable in acid or alkaline conditions. The $\mathrm{pH}$ stability of chitinase from Bacillus cereus and Bacillus sp. NCTU2 were 2.5 to 8 (YiWang et al. 2001 and Min-Wen et al. 2002). The pH stability of chitinase from isolate 99 and Enterobacter sp. G-1 in this experiment was within this reported range.

Chitinase activity from isolate 99 was increased to 41.03, 128.21 , and $466.67 \%$ respectively after being incubated with $\mathrm{Fe}^{2+}, \mathrm{Ba}^{2+}$, and $\mathrm{Co}^{2+}$, while chitinase activity from Enterobacter sp. G-1was increased up to $120 \%$ after being incubated with $\mathrm{Ca}^{2+}$ and $748.28 \%$ with $\mathrm{Co}^{2+}$. Chitinase activity from Enterobacter sp. G-1 was decreased to 20.69 $\%$ after being incubated with $\mathrm{Ba}^{2+}$. In general chitinase activity was inhibited by $\mathrm{Hg}^{2+}$ and $\mathrm{Ag}^{+}$, while $\mathrm{Cu}^{2+}$ could increase or decrease chitinase activity. In some fish species and microorganism like Pseudomonas aeruginosa, their chitinase activities are increased by $\mathrm{Cu}^{2+}$ (Jolle's and Muzzarelli 1999). Some chitinase enzymes are very sensitive to metal ions. For example, chitinase activity from Aspergillus fumigatus was inhibited strongly by $\mathrm{Hg}^{2+}, \mathrm{Pb}^{2+}$, $\mathrm{Ag}^{+}, \mathrm{Fe}^{2+}, \mathrm{Mn}^{2+}$, and $\mathrm{Zn}^{2+}$ (Xia et al. 2001). Chitinase activity from Bacillus brevis was inhibited by $\mathrm{Ag}^{+}$after incubated in $1 \mathrm{mmol} \mathrm{l}^{-1} \mathrm{Ag}^{+}$at $\mathrm{pH} 8$ and $30^{\circ} \mathrm{C}$ for $30 \mathrm{~min}$ and only $60 \%$ of the enzyme activity remained (Sheng et al. 2004). Howard et al. (2004) reported that chitinase B of Microbulbifer degradans 2-40 has two catalytic domains (GH18N and GH18C), and the activity of each domain was not affected by a $10 \mathrm{mM}$ concentration of various chloride salts: $\mathrm{Mg}^{2+}$, $\mathrm{Mn}^{2+}, \mathrm{Ca}^{2+}, \mathrm{K}^{+}$, but the activity of $\mathrm{GH} 18 \mathrm{~N}$ was reduced $36 \%$ by $\mathrm{Ni}^{2+}, 8 \%$ by $\mathrm{Sr}^{2+}$, and $41 \%$ by $\mathrm{Cu}^{2+}$, while the activity of GH18C was reduced $14 \%$ by $\mathrm{Ni}^{2+}, 5 \%$ by $\mathrm{Sr}^{2+}$ and $53 \%$ by $\mathrm{Cu}^{2+}$. $\mathrm{Hg}^{2+}$ completely inhibited the activities of both domains. The metal ion sensitivity of chitinase from isolate 99 strain and Enterobacter sp. G-1 in this experiment was not the same as reported previously, its activity was not inhibited by $\mathrm{Fe}^{2+}, \mathrm{Ba}^{2+}, \mathrm{Ca}^{2+}, \mathrm{Cu}^{2+}$, and $\mathrm{Co}^{2+}$, except that for chitinase from Enterobacter sp. G-1 which was decreased by $\mathrm{Ba}^{2+}$ (Table 1$)$. Its response to other ions is still unknown.

In conclusion, the chitinase characteristics (enzyme activity, temperature, $\mathrm{pH}$, and the effect of metal ion on chitinase activity) from isolate 99 were better and it was more tolerant than those of Enterobacter sp. G-1. Several ions $\left(\mathrm{Fe}^{2+}, \mathrm{Ba}^{2+}, \mathrm{Co}^{2+}\right)$ increased the activity of the enzyme from isolate 99, while $\mathrm{Ca}^{2+}$ and $\mathrm{Co}^{2+}$ increased the activity of chitinase from Enterobacter sp. G-1 but $\mathrm{Ba}^{2+}$ decreased its activity.

\section{ACKNOWLEDGEMENTS}

This experiment was supported by a BPPS scholarship from Directorate General of Higher Education, Department of National Education Republic of Indonesia. I thank to Kawamukai of Shimane University, Japan for his given me permission for using the bacteria collection at the Biochemistry and Biotechnology Laboratory, Faculty of Life and Environmental Science, Shimane University.

\section{REFERENCES}

Dahiya N, Tewari R, Tiwari RP, Hoondal GS. 2005. Chitinase from Enterobacter sp. NRG4: its purification, characterization, and reaction pattern. Electr J Biotechnol 8(2). 10 p. [on line]. http:// www.ejbiotechnology.info/content/vol 8/issu 2/full/6/index.html.

Howard MB, Ekborg NA, Taylor LE, Weiner RM, Hutcheso SW. 2004. Chitinase B of Microbulbifer degradans 2-40 contains two catalytic domains with different chitinolytic activities. Bacteriol 186:12971303.

Imoto T, Yagashita K. 1971. A simple activity measurement of lysozyme. Agric Biol Chem 35:1154-1156.

Jolle‘s P, Muzzarelli RAA. 1999. Chitin and chitinase. Birkhauser Verlag Basel, Switzerland 98:111-123.

Koga D, Mitsutomi M, Kono M, Matsumiya M. 1999. Biochemistry of chitinases in chitin and chitinase. Jolle's P, Muzzarelli RAA (eds). Birkhauser Verlag: Basel, Switzerland 98:111-123.

Lowry OH, Rosebrough HPJ, Farr AL, Randall RJ. 1951. Protein measurement with the valin phenol reagent. Biochem 193:256-275. 
Mahata ME, Yun CS, Abdi D, Irsan R, Yose R, Kawamukai M. 2005. Karakterisasi kitosanase ekstraseluler dari bakteri asal air dan tanah di kota Matsue, Jepang dan dibandingkan dengan kitosanase dari Matsuebacter chitosanotabidus 3001. J Mikrobiol Indonesia 10:21214.

Min-Wen C, Tseng CS, Cheng CY, Li, Yk 2002. Purification characterization and cloning of a chitinase from Bacillus sp. NCTU 2. Biotechnol Appl Biochem 35:213-219.

Minoru M, Hiroyuki S, Yoshihiro S. 2002. Control of function of chitin and chitosan by chemical modification. Mini review, in trends in glycoscience and glycotechnology 14:205-222.

Park JK, Morita K, Fukumoto I, Yamasaki Y, Nakagawa T, Kawamukai M, Matsuda H. 1997. Purification and characterization of the chitinase (ChiA) from Enterobacter sp. G1. Biosci Biotechnol Biochem 61:684689.

Reyes MP, Corona FG. 1997. The bifunctional enzyme chitosanasecellulase produced by the gram negative microorganism Myxobacter sp. Al-1 is highly similar to Bacillus subtilis endoglucanases. Arch Microbiol 168:321-327.

Sheng L, Zhi-an Z, Ming L, Zhen-Rong G, Chen BAI, Weida H. 2004. Purification and characterization of a novel chitinase from Bacillus brevis. Acta Biochim Biophys Sinica 34:690-696.

Shimosaka M, Nogawa M, Wang XY, Kumehara M, Okazaki M. 1995. Production of two chitosanases from a chitosan-assimilating bacterium, Acinetobacter sp. strain CHB101. Appl Environ Microbiol 61:438-442.
Thompson SE, Smith M, Wilkinsons MC, Peek K. 2001. Identification and characterization of a chitinase antigen from Pseudomonas aeruginosa strain 385. Appl Environ Microbiol 67:4001-4008.

Ueda M, Kojima M, Yoshikawa T, Mitsuda N, Araki K, Kawaguchi T, Miyatake K, Arai M, Focalize T. 2003. A novel type of family 19 chitinase from Aeromonas sp. no. 10 S-24 cloning, sequence, expression, and the enzymatic properties. Eur J Biochem 270: 25132520

Watanabe T, Oyanagi W, Suzuki K, Tanaka H. 1999. Chitinase system of Bacillus circulans WL-12 and importance of chitinase A1 in chitin degradation. Bacteriol 172:4017-22.

Xia G, Chunsheng J, Ju Z, Shoujun Y, Shuzheng Z, Cheng J. 2001. A novel chitinase having a unique mode of action from Aspergillus fumigatus YJ-407. Eur Biochem 268:4079-4085.

Yamasaki Y. 1993. Studies on chitinolytic and chitosanolytic enzymes produced by a bacterium and their application [Thesis]. Japan: Shimane University.

Yi-Wang S, Anne LM, George T, Shaw JW, Robert DL, Narendra K, Singh. 2001. Purification and characterization of a Bacillus cereus exochitinase. Enzyme Microb Technolo 28:492-498.

Zhang Z, Yuen GY, Sarath G, Penheiter AR. 2001. Chitinase from the plant disease biocontrol agent, Stenotrophomonas maltophilia C3. The american phytopalthological society. 